\title{
Vitamin D deficiency: concern for rheumatoid arthritis and COVID-19?
}

\author{
Sneha Verma ${ }^{1} \cdot$ Ved Chaturvedi $^{2}$. N. K. Ganguly ${ }^{1} \cdot$ Shivani Arora Mittal ${ }^{1}[$ \\ Received: 27 February 2021 / Accepted: 16 August 2021 / Published online: 28 August 2021 \\ (c) The Author(s), under exclusive licence to Springer Science+Business Media, LLC, part of Springer Nature 2021
}

\begin{abstract}
Vitamin D is an immunomodulatory hormone with an established role in calcium and phosphate metabolism and skeletal mineralization. Evidence showing its immunological benefits by regulating essential components of the innate and adaptive immune system is prevalent. Vitamin D deficiency is reported worldwide and is thereby found to be associated with various immune-related diseases. Rheumatoid Arthritis and COVID-19 are two such diseases, sharing a similar hyperinflammatory response. Various studies have found an association of lower Vitamin D levels to be associated with both these diseases. However, contrasting data is also reported. We review here the available scientific data on risk factor association and supplementation benefits of Vitamin D in Rheumatoid Arthritis and COVID-19, intending to critically evaluate the literature.
\end{abstract}

Keywords Vitamin D · Deficiency · Association · Rheumatoid arthritis · COVID-19 · Supplementation

$\begin{array}{ll}\text { Abbreviations } \\ \text { TNF-alpha } & \text { Tumor necrosis factor-alpha } \\ \text { IL-6 } & \text { Interleukin 6 } \\ \text { IL-8 } & \text { Interleukin } 8 \\ \text { IL-17 } & \text { Interleukin 17 } \\ \text { GM-CSF } & \text { Granulocyte-macrophage-colony stimulating } \\ & \text { factor } \\ \text { CCL2 } & \text { Monocyte chemoattractant protein 1 } \\ \text { CXCL10 } & \text { C-X-C motif chemokine ligand 10 } \\ \text { CCL3 } & \text { Chemokine (C-C motif) ligand 3 } \\ \text { VDR } & \text { Vitamin D receptor } \\ \text { SLE } & \text { Systemic lupus erythematosus } \\ \text { NET } & \text { Neutrophil extracellular traps } \\ \text { NOD2 } & \text { Nucleotide-binding oligomerization domain- } \\ & \text { containing protein 2 } \\ \text { mTOR } & \text { Mammalian target of rapamycin } \\ \text { PI3KC3 } & \text { Class III phosphatidylinositol 3-kinase } \\ \text { RCT } & \text { Randomized clinical trial } \\ \text { DAS28 } & \text { Disease activity score 28 } \\ \text { VAS } & \text { Patient global pain score } \\ \text { ESR } & \text { Erythrocyte sedimentation rate } \\ \text { SJC } & \text { Swollen joint count } \\ & \end{array}$

Shivani Arora Mittal

shivanimittal@icloud.com

1 Department of Research, Sir Ganga Ram Hospital, New Delhi, India

2 Department of Rheumatology \& Clinical Immunology, Sir Ganga Ram Hospital, New Delhi, India

\author{
CRP C reactive protein \\ ACE2 Angiotensin-converting enzyme 2 \\ ARDS Acute respiratory distress syndrome \\ MASP2 Mannose-binding lectin (MBL)-associated \\ serine protease 2 \\ C5 Complement component 5 \\ CAD Coronary artery disease \\ MKP1 Mitogen-activated protein kinase \\ phosphatase-1
}

\section{Introduction}

Vitamin D, a secosteroid, primarily exists in 2 forms, Ergocalciferol (vitamin D2) and Cholecalciferol (vitamin D3). Its deficiency is a common global health concern and contributing factors include diet, geographic location, and ethnicity [1]. Generally, vitamin D levels less than $20 \mathrm{ng} / \mathrm{ml}$ are defined as 'deficient and less than $30 \mathrm{ng} / \mathrm{ml}$ as 'insufficient. Its key roles include maintaining calcium homeostasis throughout circulation and skeletal mineralization. It is reported to have an anti-inflammatory role and established benefits in osteoporosis and osteomalacia [2]. Observational studies have reported a negative correlation between vitamin $\mathrm{D}$ levels and various diseases such as diabetes, cardiovascular, autoimmune diseases, and cancer [3]. However, contrasting reports suggesting no association also exist, for example in a study in CAD patients, no association with angiogenic 
severity was found [4]. Hence, role of vitamin D in various diseases needs detailed analysis.

Vitamin D deficiency has been associated with incidence and severity of Rheumatoid Arthritis (RA), an autoimmune syndrome, and supplementation is also clinically prescribed. Recently, various reports implicating Vitamin D deficiency as a possible risk factor for COVID-19 incidence and severity are also emerging. Both RA and COVID-19 have shared pathological mechanisms. A common pro-inflammatory cytokine (TNF-alpha, IL-6, IL-8, IL-17, GM-CSF) and chemokine profile (CCL2, CXCL10, CCL3) is frequently reported [5, 6]. Similar radiological aspects of pneumonia (Ground-glass opacities and vascular enlargement) are also observed in the two diseases. Various anti-rheumatic strategies, like IL-6 inhibitor (Tocilizumab) and JAK inhibitor (Baricitinib) are being investigated for COVID treatment [7-10]. Observational, meta-analysis and multi-omics approach-based studies indicate that the autoimmune disease group patients are at significant risk for COVID-19 infection [11-13] which calls for the inclusion of adjuvant therapies. In lieu of the above, we have reviewed here the scientific literature on vitamin D deficiency as a risk factor and its supplementation benefits in RA and COVID diseases.

\section{Methods}

\section{Information source and search keywords}

Studies were extracted from the following electronic databases: PubMed, Google Scholar, and Connected Papers. The search criteria included English language original articles that were identified using the following keywords "vitamin D association", "rheumatoid arthritis", "vitamin D COVID19 association", "vitamin D supplementation" from 2016 onwards.

\section{Study selection}

Titles and abstracts were evaluated for inclusion (English language original articles from 2016 onwards on vitamin D association and supplementation in Rheumatoid Arthritis and COVID-19 infection) or exclusion (studies reporting mixed reports on vitamin D association, related to other autoimmune diseases or respiratory infections). If eligible for inclusion, full-text articles were read and evaluated.

\section{Data collection process}

The following data were extracted from the articles: title, journal, authors, and year of publication, study design, sample size, main findings, and limitations. This information was evaluated and classified accordingly in a tabular form.

\section{Vitamin D: immunomodulatory function}

Apart from Vitamin D's well-known functions in calcium and bone homeostasis, it exerts substantial immunomodulatory action through transcriptional and epigenetic mechanisms. This is evident from widespread expression of Vitamin D Receptor (VDR) in most immune cell types and their ability to express CYPB21 enzyme, which metabolizes vitamin $\mathrm{D}$ into its active form, $1,25(\mathrm{OH})_{2} \mathrm{D}_{3}$ [14]. Alterations in the VDR gene have been indicated in several diseases including Diabetes Mellitus [15], Pulmonary Tuberculosis [16], Systemic Lupus Erythematosus (SLE) [17], and Rheumatoid Arthritis [18].

Vitamin D reduces microbial infection and death through various mechanisms, including regulating physical barrier and innate and adaptive immune cells. It also helps maintain tight junctions, gap junctions and adherent junctions [19]. It induces various pathways like autophagy in monocytes [20]; phagocytic ability, ROS production, chemotaxis, and induction of VDR responsive genes (e.g.: antimicrobial peptides) in activated macrophages; increased microbicidal activity and reduced NET formation in neutrophils. Vitamin D also prevents dendritic cells from maturing, by reducing their expression of MHCclassII and costimulatory molecules, resulting in a more tolerogenic and anti-inflammatory phenotype. Additionally, it is shown to inhibit plasma cell and post-switch memory B cell formation. It represses Th1 cell formation and stimulates Th2 cells along with the formation of regulatory $\mathrm{T}$ cells [21]. The vitamin $\mathrm{D}$ mediated cytokine regulation through various effectors is shown in Fig. 1. It regulates the epigenetic programming of immune cells (mainly monocytes, macrophages, and dendritic cells) during immune challenges and thereby affects their immunological memory and subtype differentiation [22]. It also stimulates endothelial NOS production and has pleiotropic effects on the vascular endothelium that are protective against injury due to inflammation [23].

Various anti-inflammatory mechanisms attributed to vitamin D are, inhibition of Prostaglandin (PG) synthesis, nuclear translocation of NF-kB [24], stress-activated kinase signaling, and production of inflammatory cytokines [25]. Prostaglandins are pro-inflammatory molecules and play important role in mediating cell proliferation, differentiation, and apoptosis. They are reported to increase TNF-alpha, IL-6, CXCL1, and COX-2 levels, mediating the inflammatory cascade [26]. Vitamin D inhibits PG mediated inflammation through three mechanisms: reduced PG receptor, reduced COX-2 expression 
Fig. 1 Immunomodulatory Effects of Vitamin D. The figure describes some of the gene targets of vitamin D and its effect on innate as well as adaptive immune system. Cathelicidin antimicrobial peptide (CAMP), Integrin alpha $\mathrm{M}$ (ITGAM), CD93, Nuclear Factor NFKappa-B (NFKB1A), Receptor Activator of Kappa-B Ligand (RANKL), Cyclooxygenase-2 (Cox-2)

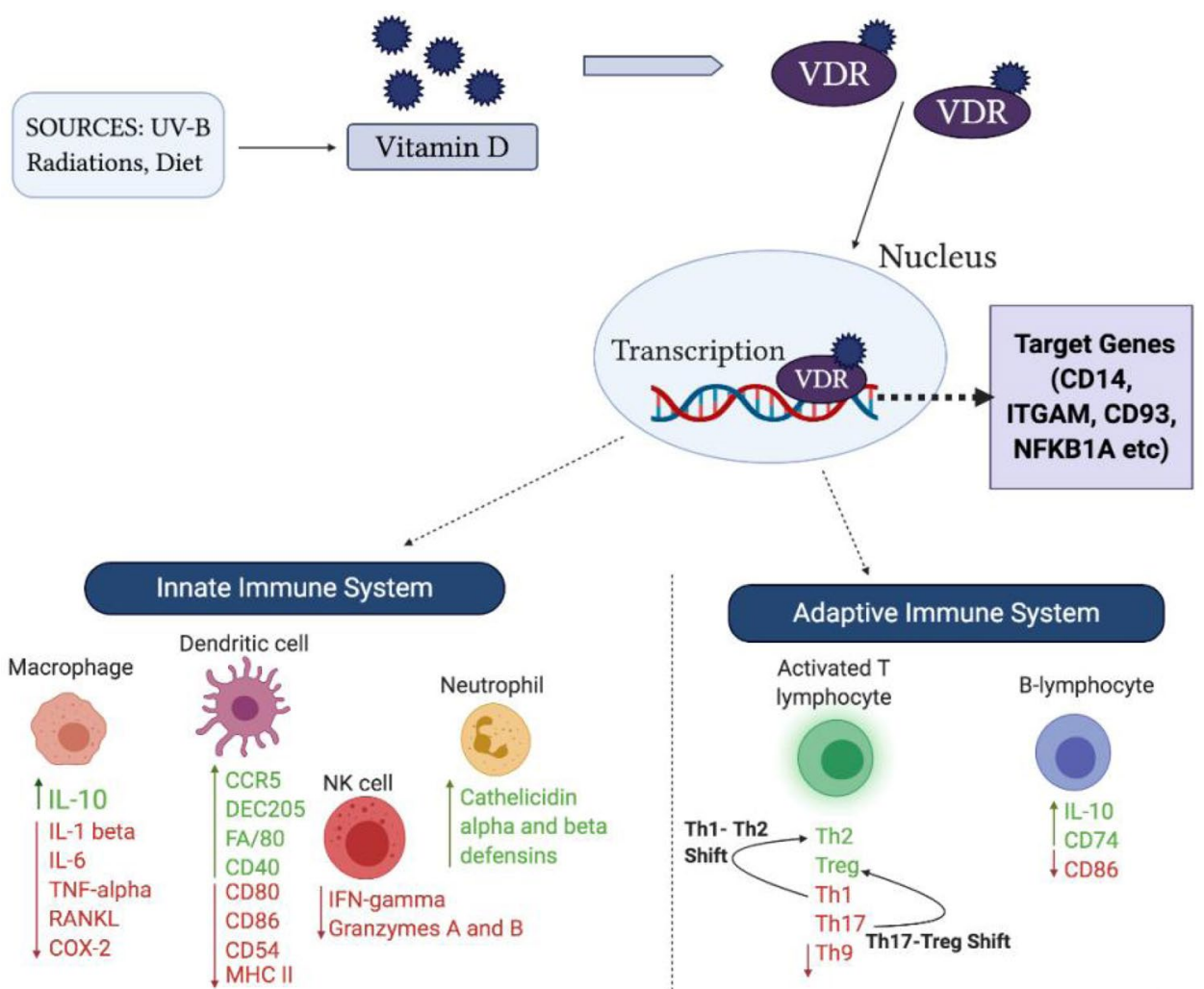

and increased 15-PGDH (PG Dehydrogenase) expression [27]. Studies also reveal inhibitory action of vitamin D on Lipopolysaccharide (LPS)-induced p38 phosphorylation along with TNF-alpha and IL-6 expression [28, 29]. Significant anti-inflammatory effects of vitamin $\mathrm{D}$ were also observed by inhibiting expression of TNF-alpha, COX2 , and iNOS (inducible nitric oxide synthase), using the classical model of inflammation in mice [30].

Antimicrobial and antiviral actions of vitamin D are mediated through induced expression of peptides such as Cathelicidin, Beta-defensin 2, Nucleotide-binding Oligomerization Domain-containing protein 2 (NOD2). Cathelicidin induces activation of pro-inflammatory cytokines, neutrophil chemotaxis, monocytes, and $\mathrm{T}$ cells at the site of infection. Additionally, it blocks viral entry and suppresses viral replication. Vitamin D also suppresses bacterial growth through suppression of Hepcidin, which restricts the export of iron, thereby increasing intracellular iron. Decreased Hepcidin activity also promotes activation of Ferroportin, followed by increased transcellular export of iron. Since iron is one of the crucial factors for bacterial survival, decreased levels lead to reduce bacterial growth. Vitamin D also induces autophagy, by downregulating mTOR pathway and inducing Beclin 1 and PI3KC3, the key enzymes driving autophagy. Vitamin D-mediated autophagy is found to reduce many viral infections like HIV-1, influenza A, rotavirus and hepatitis $C$ [31].

\section{Vitamin D: role in rheumatoid arthritis}

Rheumatoid Arthritis (RA) is a chronic autoimmune condition, resulting in synovial inflammation around joints, progressively leading to cartilage and bone destruction. Although the main cause is unknown, various factors are involved in its pathogenesis, including genetic, environmental, and dietary components.

A large body of epidemiological data demonstrates that vitamin D insufficiency/deficiency is associated with various disease conditions, especially of the musculoskeletal and autoimmune types. An inverse association between serum vitamin D levels and RA incidence and disease activity is widely reported [32-36]. Some reports with larger sample sizes also have shown similar associations. Lee used a meta-analysis approach from data of more than 1,100 patients to conclude an inverse association with RA prevalence and activity [37]. In another cross-sectional observational analysis of 1413 patients from different countries across latitudes, similar results were obtained 
[38]. In addition, in treatment-naïve RA patients, a significant negative association was observed between vitamin D levels and disease activity parameters [34]. Recently, in a study with 645 early RA patients, vitamin D deficiency correlated with more active and severe disease and was suggested as a useful biomarker to predict disability progression over one year [39]. However, contrasting data showing no association is also reported [40, 41]. Reports demonstrating vitamin D insufficiency to be associated with RA prevalence along with its immunosuppressive role have led to further studies evaluating its preventive/ therapeutic supplemental benefit. In a prospective cohort study of 152 elderly RA women through 11 years of follow-up, total dietary and supplemental vitamin D intake was found associated with reduced RA risk. However, here patients were not clinically assessed and sunlight exposure was not taken into account [42]. In a randomized interventional study on 73 RA patients with low DAS28 scores and vitamin D levels, a significant improvement in mean scores was seen with vitamin D supplementation over 3 months [43]. A randomized trial conducted in 150 patients from India concluded that weekly supplementation of $60,000 \mathrm{IU}$ in early treatment-naïve RA patients resulted in greater pain relief [44]. In a meta-analysis of six RCTs with 438 participants, vitamin D complementary therapy resulted in more beneficial effects on DAS28, ESR. However, no improvement was observed in other parameters such as VAS (Patient Global Pain Score), SJC (Swollen Joint Count), CRP. Notably, in a subgroup analysis, a significantly improved VAS score was observed with vitamin D supplementation of more than 50,000 IU/week, for more than 12 weeks [45]. In another small cohort (61) study, supplementation with 1,00,000 IU/month, resulted in a significant decline in DAS and VAS scores in only vitamin D sufficient patients [46]. Another randomized, interventional study evaluating the relationship between vitamin D deficiency and RA concluded significant improvement in disease activity after administrating vitamin $\mathrm{D}$ in specific concentrations along with other therapeutic drugs [43]. This suggests that the dose and duration of supplementation could be a critical determinant of the overall response. However, few studies found no additional clinical benefit after vitamin D supplementation [47-49]. Also, in a meta-analysis of 5 studies, no significant association was observed between vitamin D supplementation and RA recurrence [50]. Significant studies on the association of vitamin D with RA incidence/severity and its supplemental benefit are described in Table 1. Thus, although the association of vitamin $\mathrm{D}$ with incidence and severity of RA patients is conclusive, there is a lack of robust evidence supporting its supplementation in improving clinical outcome, due to heterogeneity in dosages and durations of supplementation. Hence, well-conducted large RCTs with rigorous research designs and appropriate clinical endpoints are required to determine the efficacy of vitamin D supplementation.

\section{Vitamin D: role in COVID-19}

Coronavirus disease 2019 (COVID-19), is an ongoing pandemic, caused by a novel beta coronavirus, SARS CoV-2 [57]. It is found to majorly cause a severe respiratory type illness along with direct and indirect effects on other organs, including neurological and musculoskeletal systems. Autopsy reports from severe cases revealed venous thromboembolism, fibrin deposition, widespread penetration by immune cells, and excessive alveolar damage. Involved pathologies includes exacerbated systemic inflammation with infiltration of immune cells, necrosis and hyperplasia of lung tissue, endothelial dysfunction and a pro-coagulatory state [58]. Unregulated Complement activation is considered a key pathological mechanism $[59,60]$. Terminal complement components like C5-9, MASP2, and CD4 were found to colocalize with the spike glycoproteins in lung and also found in the microvasculature in COVID patients [61]. Growing evidence suggests deposition of complement activation products, C5b-9 in lung, skin and kidney vasculature in COVID patients and supports targeting of $\mathrm{C} 5$ as a possible therapeutic intervention $[62,63]$.

Vitamin D has long been known for its antiviral effects. Its deficiency is associated with higher risk of developing Influenza/respiratory illness, Dengue, Hepatitis, HIV and other viral diseases. It is known to inhibit production and secretion of cytokines from bronchial smooth muscle cells like RANTES, PDGF, MMPs, leading to reduced smooth muscle proliferation and lung inflammation. As for COVID-19, vitamin D may regulate the pathophysiology of the disease by various mechanisms. Most of the mortalities in COVID-19 patients are due to Acute-RespiratoryDistress-Syndrome (ARDS). ARDS is characterized as a heightened inflammatory response of lung macrophages. Certain reports suggest an involvement of vitamin D in the modulation of macrophage response in COVID-19 [64]. The SARS-CoV-2 virus enters the lung cells through the ACE2 receptor, and subsequently downregulates these, leading to an increased risk of pulmonary edema [31]. Vitamin D, on the contrary, upregulates the ACE2 receptors, potentially reversing this effect. Vitamin D deficiency promotes the Renin-Angiotensin system which may lead to cardiovascular disease and reduced lung function [65]. Interestingly, DPP-4/CD26 receptor binding is one of the pathological mechanisms of closely related COVID-MERS and similar binding of this receptor has been predicted with the SARS-Cov-2 spike glycoprotein [66]. Vitamin D 


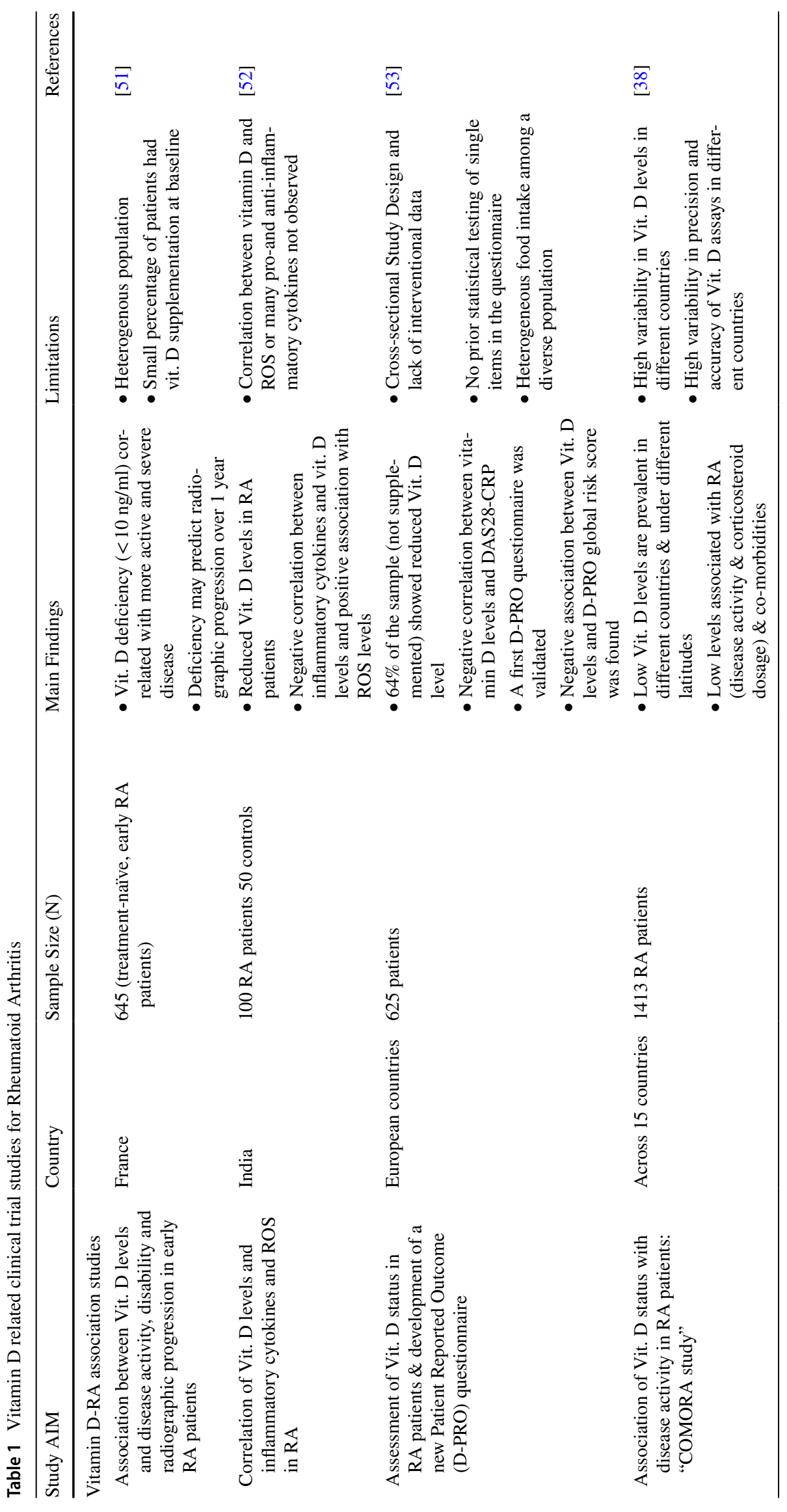




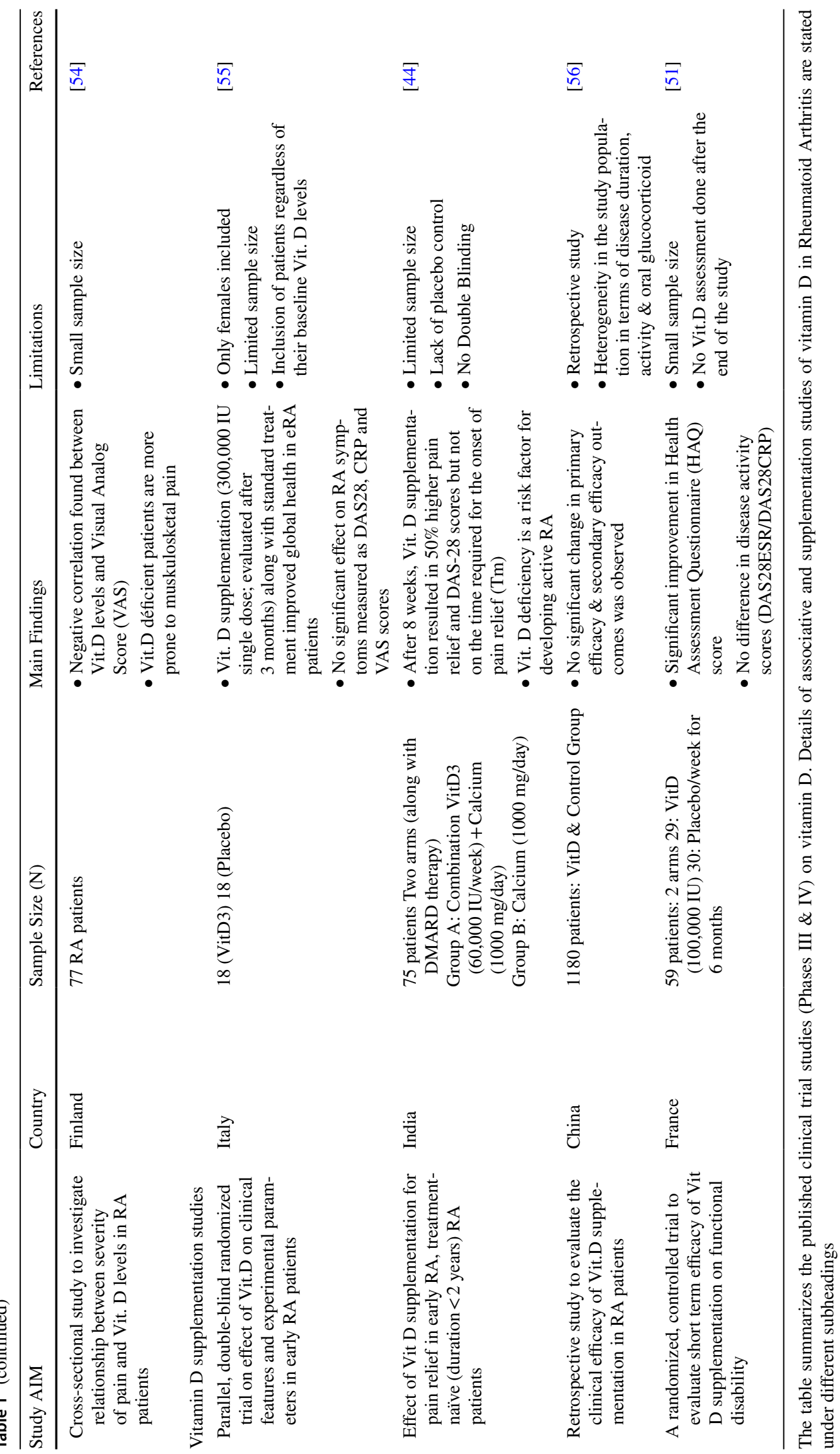


is shown to significantly reduce the expression of DPP-4/ CD26, suggesting its potential for attenuating COVID-19 infection [67]. Studies indicate that vitamin D ameliorates the key immunomodulators with prognostic value in COVID-19, like IL-6 and CRP [68]. Additionally, the cardiac features and vasculopathies observed in COVID19 could also be related to vitamin $\mathrm{D}$ deficiency.

Circumstantial evidence also points to the association of vitamin D levels with COVID outcomes. The spread of the virus began in the northern hemisphere during the end of winter (2019) when the vitamin D levels are already low. The burden of mortality has been similarly higher in the northern hemisphere. Various retrospective studies have also found a positive correlation of vitamin D levels with severity and mortality in COVID patients [69-71]. However, there are contradictory reports as well. In a UK Biobank analysis of 449 COVID-positive patients, no association was found between vitamin D levels and COVID incidence after adjusting for potential cofounders [72]. However, their samples were not representative of the general population. A prospective observational study provided primary evidence for disturbed parathyroid hormone (PTH) — vitamin D levels in severe cases of COVID-19, however, a definitive association of low vitamin D levels with disease severity and symptoms such as impaired pulmonary function testing could not be obtained [73].

Various ongoing trials are evaluating Vitamin D supplementation for its prophylactic and therapeutic benefit for COVID. An ongoing phase IV trial is investigating the efficacy of its supplementation in reducing disease severity and elucidating anti-inflammatory response in older COVID patients ( $>50$ years) (NCT04482673). Comparison of Standard (50,000 IU) and High Dose (4,00,000 IU) one time vitamin $\mathrm{D}$ supplementation is also ongoing in a multicentric superiority high-risk COVID Phase III trial (CoVitTrial, NCT04344041) [74]. Additionally, Vitamin D supplementation as a prophylactic intervention is also being explored in healthcare workers (NCT04535791). A clinical case series of 4 COVID patients is reported wherein vitamin $\mathrm{D}$ deficient patients showed clinical improvements upon supplementation. Increased levels of vitamin D in blood serum after administration resulted in a significant decrease in IL-6 levels, providing insights into the mechanism of action in COVID patients [75]. Results obtained are limited to an extremely small number of patients and to validate the efficacy of vitamin D supplementation, randomized clinical trials are again required. A planned pragmatic, randomized, double-blind trial (VIVID) to assess the effect of vitamin $\mathrm{D}$ supplementation for early treatment and post-exposure prophylaxis of COVID-19 patients is ongoing. The study population consists of 1500 newly diagnosed individuals receiving a daily dose of 3200 IU vitamin D3 (9600 IU vitamin D3 on the first 2 days) or placebo (for the control group) for four weeks [76]. Key studies exploring association of Vitamin D deficiency and its supplementation benefit in COVID patients are summarized in Table 2. Hence, although there is not enough evidence to conclude a strong association of vitamin D deficiency with COVID incidence or severity, randomized controlled trials and cohort studies with larger sample sizes are required to prove this.

\section{Discussion}

A significant proportion of the population worldwide is vitamin D deficient. However, there is no formal universal consensus on circulating serum levels of $25(\mathrm{OH}) \mathrm{D}$, which define deficiency and various definitions exist. Data from animal studies suggest that vitamin D suppresses arthritis [85]. Various prospective studies also indicate vitamin D deficiency to be associated with RA incidence. However, its dietary supplemental benefit is not yet clearly established. Hence larger randomized trials with clearly defined clinical outcomes, which take into account sunlight exposure and include measurement of serum $25(\mathrm{OH}) \mathrm{D}$ levels, are required. In addition, potential limitations of accounting for confounding factors and reverse casualty need to be addressed in study designs. For instance, old-age RA patients with restricted mobility and requiring repeated hospitalization would be spending lesser time in the sunlight, leading to vitamin D deficiency, rather than the reverse. Moreover, vitamin D deficiency is also found to correlate with various chronic conditions of the kidney and heart, and hence it is unclear if the deficiency is the cause or effect of the disease.

Vitamin D metabolites have been shown to have antiviral effects ranging from the release of antimicrobial peptides and autophagy. However, there is limited preclinical data available exploring vitamin D's role in SARS-CoV-2 infection. Few epidemiological studies have revealed a link between circulating levels of vitamin $\mathrm{D}$ and the severity of COVID-19 infection. However, contrasting reports showing no such association are also available. These studies have limitations because of the use of previously measured vitamin D levels, which may not reflect the status at the time of infection. Also, other confounding effects may be present. There are several ongoing trials for assessing the supplementary benefit of vitamin D in COVID patients. Such supplementation studies are also challenging because patients present to hospitals in the hyperinflammatory stage, which may be too late for any benefit, and also because it would be difficult to assess the advantage of a micronutrient in presence of a strong anti-inflammatory agent such as Dexamethasone. Hence, a population-based trial on prophylactic benefits of vitamin D in mitigating COVID-19 infections may be more befitting. 


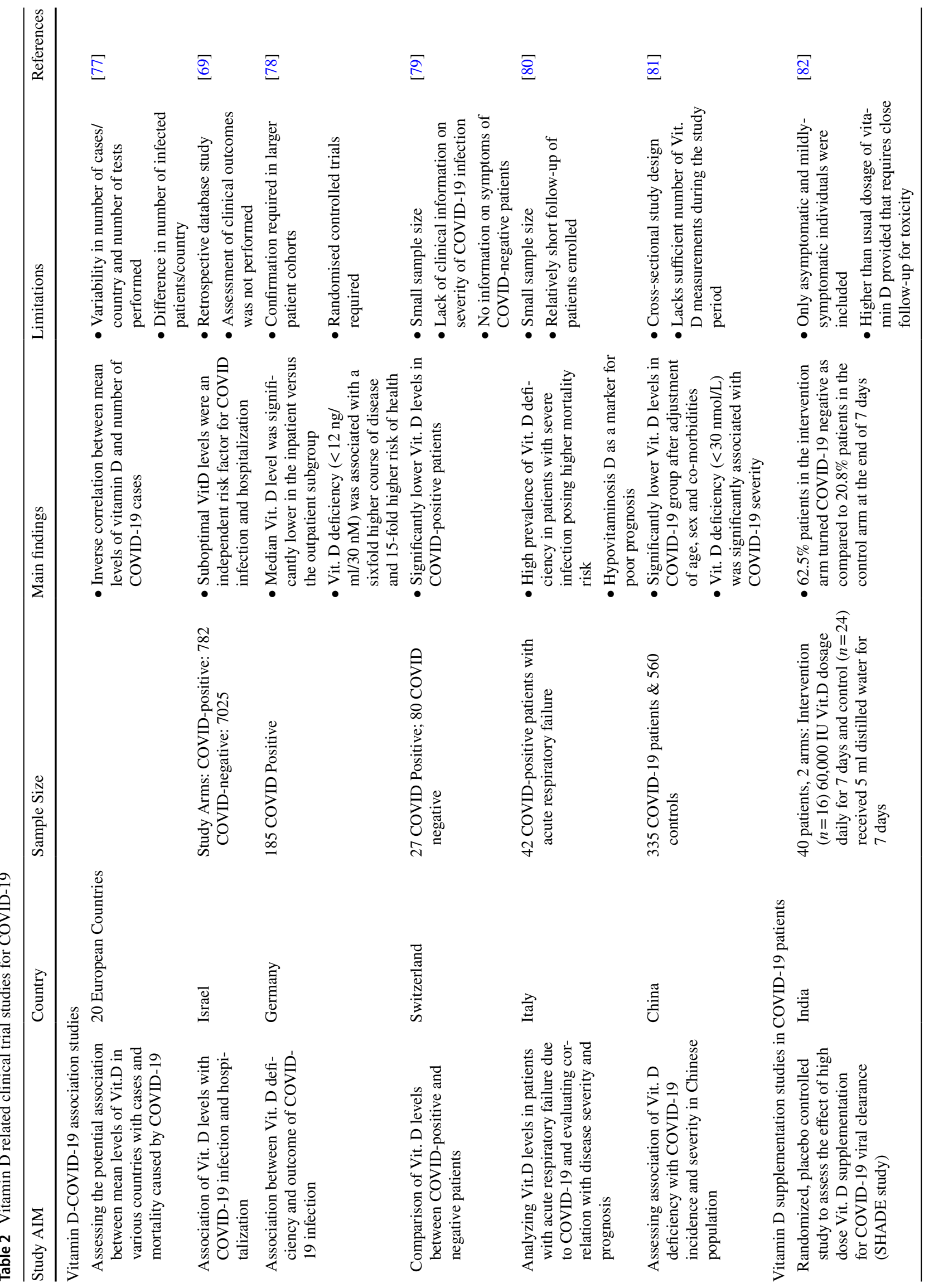




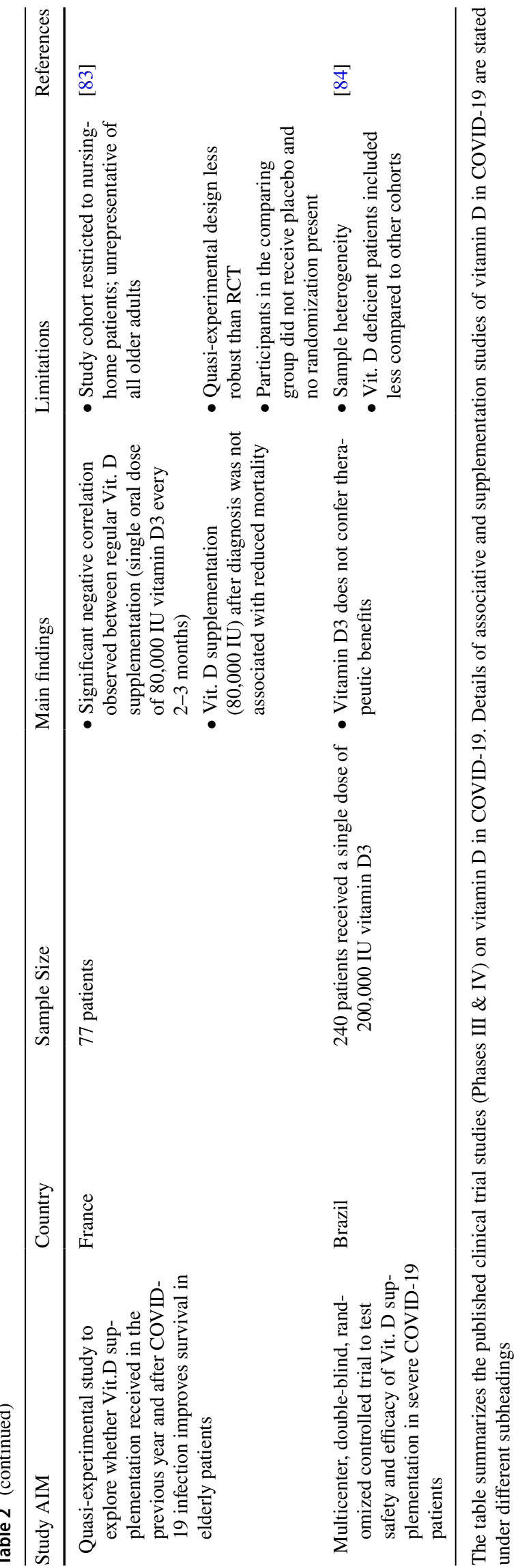

Recently, evidence suggesting association of severe COVID-19 infection with reduced Vitamin D levels is growing. In a meta-analysis, Bassatne et al. found no significant association between low Vitamin D levels and COVID19-related outcomes. However, they noticed a positive trend between low serum 25(OH)D levels ( $<20 \mathrm{ng} / \mathrm{ml})$ and mortality, ICU admission, ventilation, and SARS-CoV-2 positivity. They observed significantly reduced serum vitamin D levels in COVID-positive patients [86]. In a first retrospective study on children and adolescents, vitamin D deficiency $(<12 \mathrm{ng} / \mathrm{ml})$ was found associated with clinical severity and inflammatory markers [87]. They also propose the need for vitamin D supplementation as a prophylactic measure in adolescents. Hence, vitamin D supplementation is now being widely suggested as a rational approach to reduce risk of COVID-19 infections and deaths [75]. For deficient population and those in high-risk category, it is suggested to take 10,000 IU/day of vitamin D supplementation (loading dose) for a few weeks with an aim to quickly achieve target serum levels of 40-60 ng/ml (100-150 nmol/L), followed by dose of 5000 IU/day for few weeks [88]. Thus, practical and safe dosing guidelines for supplementation should be drafted and implemented in deficient populations, enabling slowing down of pandemic and improved quality of life.

Acknowledgements We are grateful to Mr. Peeyush Prasad and Mr. Adarsh Goel for technical support during manuscript preparation. We acknowledge the Department of Research at Sir Ganga Ram Hospital, New Delhi, 110060, India for providing the infrastructure and facility for preparing the manuscript.

Author contributions SV: Concept \& Design, Manuscript writing \& editing, VC: Manuscript proofreading \& Final approval of the manuscript, NKG: Manuscript proofreading and Final approval of the manuscript, SM: Concept \& Design, Manuscript writing \& editing, and final approval of the manuscript.

Funding This research did not receive any specific Grant from funding agencies in the public, commercial, or not-for-profit sectors.

Code availability Biorender software (free trial version for Figure).

\section{Declarations}

Conflict of interest The authors have no financial conflict with the subject matter or materials discussed in the manuscript apart from those disclosed.

\section{References}

1. Haq A, Svobodová J, Imran S, Stanford C, Razzaque MS (2016) Vitamin D deficiency: a single centre analysis of patients from 136 countries. J Steroid Biochem Mol Biol 164:209-213. https:// doi.org/10.1016/j.jsbmb.2016.02.007 
2. Bischoff-Ferrari HA, Willett WC, Wong JB, Giovannucci E, Dietrich T, Dawson-Hughes B (2005) Fracture prevention with vitamin D supplementation: a meta-analysis of randomized controlled trials. JAMA 293(18):2257-2264. https://doi.org/10.1001/ jama.293.18.2257

3. Kulie T, Groff A, Redmer J, Hounshell J, Schrager S (2009) Vitamin D: an evidence-based review. J Am Board Fam Med 22(6):698-706. https://doi.org/10.3122/jabfm.2009.06.090037

4. Dhibar DP, Sharma YP, Bhadada SK, Sachdeva N, Sahu KK (2016) Association of vitamin D deficiency with coronary artery disease. J Clin Diagn Res 10(9):OC24-OC28. https://doi.org/ 10.7860/JCDR/2016/22718.8526

5. Huang C, Wang Y, Li X et al (2020) Clinical features of patients infected with 2019 novel coronavirus in Wuhan, China. Lancet. https://doi.org/10.1016/S0140-6736(20)30183-5

6. Schett G, Manger B, Simon D et al (2020) COVID-19 revisiting inflammatory pathways of arthritis. Nat Rev Rheumatol. https:// doi.org/10.1038/s41584-020-0451-z

7. Marks M, Marks JL (2016) Viral arthritis. Clin Med (Lond). https://doi.org/10.7861/clinmedicine.16-2-129

8. Joo YB, Lim YH, Kim KJ et al (2019) Respiratory viral infections and the risk of rheumatoid arthritis. Arthritis Res Ther. https://doi.org/10.1186/s13075-019-1977-9

9. Horby PW et al (2021) Tocilizumab in patients admitted to hospital with COVID-19 (RECOVERY): preliminary results of a randomised, controlled, open-label, platform trial. medRxiv. https://doi.org/10.1101/2021.02.11.21249258

10. Richardson P, Griffin I, Tucker C, Smith D, Oechsle O, Phelan A, Rawling M, Savory E, Stebbing J (2020) Baricitinib as potential treatment for 2019-nCoV acute respiratory disease. Lancet. https://doi.org/10.1016/S0140-6736(20)30304-4

11. Barh D, Tiwari S, Andrade BS, Weener ME, Góes-Neto A, Azevedo V, Ghosh P, Ganguly NK (2020) A novel multiomics-based identification of symptoms, comorbid conditions, and possible long-term complications in COVID-19. medRxiv. https://doi.org/10.1101/2020.12.08.20245753

12. Akiyama S, Hamdeh S, Micic D, Sakuraba A (2020) Prevalence and clinical outcomes of COVID-19 in patients with autoimmune diseases: a systematic review and meta-analysis. Ann Rheum Dis. https://doi.org/10.1136/annrheumdis-2020-218946

13. Ferri C, Giuggioli D, Raimondo V et al (2020) COVID-19 and rheumatic autoimmune systemic diseases: report of a large Italian patients series. Clin Rheumatol. https://doi.org/10.1007/ s10067-020-05334-7

14. Veldman CM, Cantorna MT, DeLuca HF (2000) Expression of 1,25-dihydroxyvitamin $\mathrm{D}(3)$ receptor in the immune system. Arch Biochem Biophys. https://doi.org/10.1006/abbi.1999.1605

15. Bid HK, Mishra DK, Mittal RD (2005) Vitamin-D receptor (VDR) gene (Fok-I, Taq-I and Apa-I) polymorphisms in healthy individuals from north Indian population. Asian Pac J Cancer Prev 6(2):147-152

16. Sharma Prithvi R, Shweta S, Mamta J, Gunja M, Ravi P, Das PK, Bamezai RNK, Tiwari PK (2011) Coding and non-coding polymorphisms in VDR gene and susceptibility to pulmonary tuberculosis in tribes, castes and Muslims of Central India. Infect Genet Evol. https://doi.org/10.1016/j.meegid.2011.05.019

17. Monticielo OA, Teixeira TdM, Chies JAB et al (2012) Vitamin $\mathrm{D}$ and polymorphisms of VDR gene in patients with systemic lupus erythematosus. Clin Rheumatol 31:1411-1421. https:// doi.org/10.1007/s10067-012-2021-5

18. Mosaad YM, Hammad EM, Fawzy Z, Abdal Aal IA, Youssef HM, ElSaid TO, Monir R, EL-Deek BS (2014) Vitamin D receptor gene polymorphism as possible risk factor in rheumatoid arthritis and rheumatoid related osteoporosis. Hum Immunol. https://doi.org/10.1016/j.humimm.2014.02.009
19. Fakhoury HMA, Kvietys PR, AlKattan W et al (2020) Vitamin $\mathrm{D}$ and intestinal homeostasis: barrier, microbiota, and immune modulation. J Steroid Biochem Mol Biol. https://doi.org/10. 1016/j.jsbmb.2020.105663

20. Yuk JM, Shin DM, Lee HM, Yang CS, Jin HS, Kim KK, Lee ZW, Lee SH, Kim JM, Jo EK (2009) Vitamin D3 induces autophagy in human monocytes/macrophages via cathelicidin. Cell Host Microbe. https://doi.org/10.1016/j.chom.2009.08.004

21. Skrobot A, Demkow U, Wachowska M (2018) Immunomodulatory role of vitamin D: a review. Adv Exp Med Biol. https://doi. org/10.1007/5584_2018_246

22. Carlberg C (2019) Vitamin D signaling in the context of innate immunity: focus on human monocytes. Front Immunol. https:// doi.org/10.3389/fimmu.2019.02211

23. Kim DH, Meza CA, Clarke H, Kim JS, Hickner RC (2020) Vitamin D and endothelial function. Nutrients. https://doi.org/10. 3390/nu12020575 (PMID: 32098418)

24. Cohen-Lahav M, Shany S, Tobvin D, Chaimovitz C, Douvdevani A (2006) Vitamin D decreases NFkappaB activity by increasing IkappaBalpha levels. Nephrol Dial Transplant 21(4):889-897. https://doi.org/10.1093/ndt/gfi254

25. Krishnan AV, Feldman D (2011) Mechanisms of the anticancer and anti-inflammatory actions of vitamin D. Annu Rev Pharmacol Toxicol. https://doi.org/10.1146/annurev-pharm tox-010510-100611

26. Chen Y, Hughes-Fulford M (2000) Prostaglandin E2 and the protein kinase A pathway mediate arachidonic acid induction of c-fos in human prostate cancer cells. Br J Cancer 82(12):2000-2006. https://doi.org/10.1054/bjoc.2000.1143

27. Liu W, Zhang L, Xu HJ, Li Y, Hu CM, Yang JY, Sun MY (2018) The anti-inflammatory effects of vitamin $\mathrm{D}$ in tumorigenesis. Int J Mol Sci 19(9):2736. https://doi.org/10.3390/ijms19092736

28. Nonn L, Peng L, Feldman D, Peehl DM (2006) Inhibition of p38 by vitamin $D$ reduces interleukin- 6 production in normal prostate cells via mitogen-activated protein kinase phosphatase 5: implications for prostate cancer prevention by vitamin D. Can Res 66(8):4516-4524. https://doi.org/10.1158/0008-5472. CAN-05-3796

29. Zhang Y, Leung DY, Richers BN, Liu Y, Remigio LK, Riches DW, Goleva E (2012) Vitamin D inhibits monocyte/macrophage proinflammatory cytokine production by targeting MAPK phosphatase-1. J Immunol 188(5):2127-2135. https://doi.org/10.4049/ jimmunol.1102412 (Baltimore, Md.: 1950)

30. Lima LA et al (2020) Vitamin D (VD3) antioxidative and antiinflammatory activities: peripheral and central effects. Eur J Pharmacol 879:173099. https://doi.org/10.1016/j.ejphar

31. Bilezikian JP, Bikle D, Hewison M, Lazaretti-Castro M, Formenti AM, Gupta A, Madhavan MV, Nair N, Babalyan V, Hutchings N, Napoli N, Accili D, Binkley N, Landry DW, Giustina A (2020) MECHANISMS IN ENDOCRINOLOGY: vitamin D and COVID-19. Eur J Endocrinol 183(5):R133-R147. https://doi.org/ 10.1530/EJE-20-0665

32. Azzeh FS, Kensara OA (2015) Vitamin D is a good marker for disease activity of rheumatoid arthritis disease. Dis Markers. https:// doi.org/10.1155/2015/260725

33. Sharma R, Saigal R, Goyal L, Mital P, Yadav RN, Meena PD, Agrawal A (2014) Estimation of vitamin D levels in rheumatoid arthritis patients and its correlation with the disease activity. $\mathbf{J}$ Assoc Physicians India 62(8):678-681 (PMID: 25856934)

34. Liu Y, Wen H (2018) Impact of vitamin D deficiency on clinical parameters in treatment-naïve rheumatoid arthritis patients. Z Rheumatol 77(9):833-840. https://doi.org/10.1007/ s00393-018-0426-5

35. Jeffery LE, Raza K, Hewison M (2016) Vitamin D in rheumatoid arthritis-towards clinical application. Nat Rev Rheumatol 12(4):201-210. https://doi.org/10.1038/nrrheum.2015.140 
36. Gatenby P, Lucas R, Swaminathan A (2013) Vitamin D deficiency and risk for rheumatic diseases: an update. Curr Opin Rheumatol 25(2):184-191. https://doi.org/10.1097/BOR.0b013e32835cfc16

37. Lee YH, Bae SC (2016) Vitamin D level in rheumatoid arthritis and its correlation with the disease activity: a meta-analysis. Clin Exp Rheumatol 34(5):827-833

38. Hajjaj-Hassouni N, Mawani N, Allali F, Rkain H, Hassouni K, Hmamouchi I, Dougados M (2017) Evaluation of vitamin d status in rheumatoid arthritis and its association with disease activity across 15 countries: "The COMORA Study." Int J Rheumatol. https://doi.org/10.1155/2017/5491676

39. Mouterde G, Gamon E, Rincheval N, Lukas C, Seror R, Berenbaum F, Dupuy AM, Daien C, Daurès JP, Combe B (2020) Association between vitamin $\mathrm{D}$ deficiency and disease activity, disability, and radiographic progression in early rheumatoid arthritis: the ESPOIR cohort. J Rheumatol 47(11):1624-1628. https://doi. org/10.3899/jrheum.190795

40. Higgins MJ, Mackie SL, Thalayasingam N, Bingham SJ, Hamilton J, Kelly CA (2013) The effect of vitamin D levels on the assessment of disease activity in rheumatoid arthritis. Clin Rheumatol 32(6):863-867. https://doi.org/10.1007/s10067-013-2174-x

41. Braun-Moscovici Y, Toledano K, Markovits D, Rozin A, Nahir AM, Balbir-Gurman A (2011) Vitamin D level: is it related to disease activity in inflammatory joint disease? Rheumatol Int 31(4):493-499. https://doi.org/10.1007/s00296-009-1251-6

42. Merlino LA, Curtis J, Mikuls TR, Cerhan JR, Criswell LA, Saag KG (2004) Vitamin D intake is inversely associated with rheumatoid arthritis: results from the Iowa women's health study. Arthritis Rheum 50(1):72-77. https://doi.org/10.1002/art.11434

43. Chandrashekara S, Patted A (2017) Role of vitamin D supplementation in improving disease activity in rheumatoid arthritis: an exploratory study. Int J Rheum Dis 20(7):825-831. https://doi. org/10.1111/1756-185X.12770

44. Mukherjee D, Lahiry S, Thakur S, Chakraborty DS (2019) Effect of 1,25 dihydroxy vitamin D3 supplementation on pain relief in early rheumatoid arthritis. J Family Med Prim Care 8(2):517-522. https://doi.org/10.4103/jfmpc.jfmpc_446_18

45. Yuanyuan G, Yang H, Guan Yun Bu, Huaien WH (2020) The effect of vitamin D supplementation on rheumatoid arthritis patients: a systematic review and meta-analysis. Front Med. https://doi.org/10.3389/fmed.2020.596007

46. Adami G, Rossini M, Bogliolo L, Cantatore FP, Varenna M, Malavolta N, Del Puente A, Muratore M, Orsolini G, Gatti D, Viapiana O (2019) An exploratory study on the role of vitamin D supplementation in improving pain and disease activity in rheumatoid arthritis. Mod Rheumatol 29(6):1059-1062. https://doi.org/10. 1080/14397595

47. Salesi M, Farajzadegan Z (2012) Efficacy of vitamin D in patients with active rheumatoid arthritis receiving methotrexate therapy. Rheumatol Int 32(7):2129-2133. https://doi.org/10.1007/ s00296-011-1944-5

48. Dehghan A, Rahimpour S, Soleymani-Salehabadi H, Owlia MB (2014) Role of vitamin D in flare ups of rheumatoid arthritis. Z Rheumatol 73(5):461-464. https://doi.org/10.1007/s00393-013$1297-4.33$

49. Matsumoto Y, Sugioka Y, Tada M, Okano T, Mamoto K, Inui K, Habu D, Koike T (2015) Relationships between serum 25-hydroxycalciferol, vitamin D intake and disease activity in patients with rheumatoid arthritis-TOMORROW study. Mod Rheumatol 25(2):246-250. https://doi.org/10.3109/14397595.2014.952487

50. Franco AS, Freitas TQ, Bernardo WM, Pereira RMR (2017) Vitamin D supplementation and disease activity in patients with immune-mediated rheumatic diseases: a systematic review and meta-analysis. Med (Baltim) 96(23):e7024. https://doi.org/10. 1097/MD.0000000000007024
51. Mouterde G, Gamon E, Rincheval N et al (2020) Association between vitamin D deficiency and disease activity, disability, and radiographic progression in early rheumatoid arthritis: the ESPOIR cohort. J Rheumatol 47(11):1624-1628. https://doi.org/ 10.3899/jrheum.190795

52. Mateen S, Moin S, Shahzad S, Khan AQ (2017) Level of inflammatory cytokines in rheumatoid arthritis patients: Correlation with 25-hydroxy vitamin D and reactive oxygen species. PLoS ONE 12(6):e0178879. https://doi.org/10.1371/journal.pone. 0178879

53. Vojinovic J, Tincani A, Sulli A, Soldano S, Andreoli L, Dall'Ara F, Ionescu R, Pasalic KS, Balcune I, Ferraz-Amaro I, Tlustochowicz M, Butrimiene I, Punceviciene E, Toroptsova N, Grazio S, Morovic-Vergles J, Masaryk P, Otsa K, Bernardes M, Boyadzhieva V, Salaffi F, Cutolo M (2017) European multicentre pilot survey to assess vitamin D status in rheumatoid arthritis patients and early development of a new patient reported outcome questionnaire (D-PRO). Autoimmun Rev 16(5):548-554. https://doi.org/10.1016/j.autrev.2017.03.002.38

54. Agrawal AC, Rakshit J, Sakale H, Kar BK (2020) Assessment of musculoskeletal pain in rheumatoid arthritis patients and its relation to vitamin D levels. J Orthop Traumatol Rehabil 12(1):58

55. Buondonno I, Rovera G, Sassi F, Rigoni MM, Lomater C, Parisi S, Pellerito R, Isaia GC, D’Amelio P (2017) Vitamin D and immunomodulation in early rheumatoid arthritis: A randomized double-blind placebo-controlled study. PLoS ONE 12(6):e0178463. https://doi.org/10.1371/journal.pone.0178463

56. Jianhong Wu, Jianling D, Shilin Li, Jiaang L, Zhang Yu, Hong L, Yuanpiao Ni, Xue Li, Jun Z, Hang Y, Qianrong X, Xuejun J, Tingting W, Pingxi W, Fanwei Z, Yanpeng C, Jing Y, Fanxin $Z$ (2020) The role of vitamin D in combination treatment for patients with rheumatoid arthritis. Front Med. https://doi.org/ 10.3389/fmed.2020.00312

57. Wu F, Zhao S, Yu B, Chen YM, Wang W, Song ZG, Hu Y, Tao ZW, Tian JH, Pei YY, Yuan ML, Zhang YL, Dai FH, Liu Y, Wang QM, Zheng JJ, Xu L, Holmes EC, Zhang YZ (2020) A new coronavirus associated with human respiratory disease in China. Nature 579(7798):265-269. https://doi.org/10.1038/ s41586-020-2008-3

58. Wichmann D, Sperhake JP, Lütgehetmann M, Steurer S, Edler C, Heinemann A, Heinrich F, Mushumba H, Kniep I, Schröder AS, Burdelski C, de Heer G, Nierhaus A, Frings D, Pfefferle S, Becker H, Bredereke-Wiedling H, de Weerth A, Paschen HR, Sheikhzadeh-Eggers S et al (2020) Autopsy findings and venous thromboembolism in patients with COVID-19: a prospective cohort study. Ann Intern Med 173(4):268-277

59. Hendaus MA, Jomha FA (2020) From COVID-19 to clot: the involvement of the complement system. J Biomole Struct Dyn. https://doi.org/10.1080/07391102.2020.1832919

60. Wang X, Sahu KK, Cerny J (2021) Coagulopathy, endothelial dysfunction, thrombotic microangiopathy and complement activation: potential role of complement system inhibition in COVID-19. J Thromb Thrombolysis 51:657-662. https://doi. org/10.1007/s11239-020-02297-Z

61. Magro C, Mulvey JJ, Berlin D, Nuovo G, Salvatore S, Harp J, Baxter-Stoltzfus A, Laurence J (2020) Complement associated microvascular injury and thrombosis in the pathogenesis of severe COVID-19 infection: a report of five cases. Transl Res: J Lab Clin Med. https://doi.org/10.1016/j.trs1.2020.04.007

62. Noris M, Benigni A, Remuzzi G (2020) The case of complement activation in COVID-19 multiorgan impact. Kidney Int. https:// doi.org/10.1016/j.kint.2020.05.013

63. Diurno F, Numis FG, Porta G, Cirillo F, Maddaluno S, Ragozzino A, De Negri P, Di Gennaro C, Pagano A, Allegorico E, Bressy L, Bosso G, Ferrara A, Serra C, Montisci A, D’Amico 
M, Schiano Lo Morello S, Di Costanzo G, Tucci AG, Marchetti $P$ et al (2020) Eculizumab treatment in patients with COVID-19: preliminary results from real life ASL Napoli 2 Nord experience. Eur Rev Med Pharmacol Sci. https://doi.org/10.26355/ eurrev_202004_20875

64. Kloc M, Ghobrial RM, Lipińska-Opałka A, Wawrzyniak A, Zdanowski R, Kalicki B, Kubiak JZ (2021) Effects of vitamin D on macrophages and myeloid-derived suppressor cells (MDSCs) hyperinflammatory response in the lungs of COVID-19 patients. Cell Immunol 360:104259. https://doi.org/10.1016/j.cellimm. 2020.104259

65. Shi Y, Liu T, Yao L et al (2017) Chronic vitamin D deficiency induces lung fibrosis through activation of the reninangiotensin system. Sci Rep 7:3312. https://doi.org/10.1038/ s41598-017-03474-6

66. Vankadari N, Wilce JA (2020) Emerging WuHan (COVID-19) coronavirus: glycan shield and structure prediction of spike glycoprotein and its interaction with human CD26. Emerg Microbes Infect 9(1):601-604. https://doi.org/10.1080/22221751.2020. 1739565

67. Komolmit P, Charoensuk K, Thanapirom K, Suksawatamnuay S, Thaimai P, Chirathaworn C, Poovorawan Y (2017) Correction of vitamin D deficiency facilitated suppression of IP-10 and DPP IV levels in patients with chronic hepatitis C: a randomised doubleblinded, placebo-control trial. PLoS ONE 12(4):e0174608. https:// doi.org/10.1371/journal.pone.0174608

68. Miroliaee AE, Salamzadeh J, Shokouhi S, Sahraei Z (2018) The study of vitamin D administration effect on CRP and Interleukin-6 as prognostic biomarkers of ventilator associated pneumonia. $\mathrm{J}$ Crit Care 44:300-305. https://doi.org/10.1016/j.jcrc.2017.08.040

69. Merzon E, Tworowski D, Gorohovski A, Vinker S, Golan Cohen A, Green I, Frenkel-Morgenstern M (2020) Low plasma $25(\mathrm{OH})$ vitamin $\mathrm{D}$ level is associated with increased risk of COVID-19 infection: an Israeli population-based study. FEBS J 287(17):3693-3702. https://doi.org/10.1111/febs.15495

70. De Smet D, De Smet K, Herroelen P, Gryspeerdt S, Martens GA (2020) Vitamin D deficiency as risk factor for severe COVID-19: a convergence of two pandemics. medRxiv. https://doi.org/10. $1101 / 2020.05 .01 .20079376$

71. Lau FH, Majumder R, Torabi R, Saeg F, Hoffman R, Cirillo JD, Greiffenstein P (2020) Vitamin D insufficiency is prevalent in severe COVID-19. medRxiv. https://doi.org/10.1101/2020.04.24. 20075838

72. Hastie CE, Mackay DF, Ho F, Celis-Morales CA, Katikireddi SV, Niedzwiedz CL, Jani BD, Welsh P, Mair FS, Gray SR, O’Donnell CA, Gill JM, Sattar N, Pell JP (2020) Vitamin D concentrations and COVID-19 infection in UK Biobank. Diabetes Metab Syndr 14(4):561-565. https://doi.org/10.1016/j.dsx.2020.04.050

73. Pizzini A, Aichner M, Sahanic S, Böhm A, Egger A, Hoermann G, Kurz K, Widmann G, Bellmann-Weiler R, Weiss G, Tancevski I, Sonnweber T, Löffler-Ragg J (2020) Impact of vitamin D deficiency on COVID-19-A prospective analysis from the CovILD registry. Nutrients 12(9):2775. https://doi.org/10.3390/nu120 92775

74. Annweiler C, Beaudenon M, Gautier J et al (2020) COvid-19 and high-dose VITamin D supplementation TRIAL in highrisk older patients (COVIT-TRIAL): study protocol for a randomized controlled trial. Trials 21:1031. https://doi.org/10.1186/ s13063-020-04928-5

75. Ohaegbulam KC, Swalih M, Patel P, Smith MA, Perrin R (2020) Vitamin D supplementation in COVID-19 patients: a clinical case series. Am J Ther 27(5):e485-e490. https://doi.org/10.1097/MJT. 0000000000001222
76. Wang R, DeGruttola V, Lei Q et al (2020) The vitamin D for COVID-19 (VIVID) trial: a pragmatic cluster-randomized design. Contemp Clin Trials. https://doi.org/10.1016/j.cct.2020.106176

77. Ilie PC, Stefanescu S, Smith L (2020) The role of vitamin D in the prevention of coronavirus disease 2019 infection and mortality. Aging Clin Exp Res 32(7):1195-1198. https://doi.org/10.1007/ s40520-020-01570-8

78. Radujkovic A, Hippchen T, Tiwari-Heckler S, Dreher S, Boxberger M, Merle U (2020) Vitamin D deficiency and outcome of COVID-19 patients. Nutrients 12(9):2757. https://doi.org/10. 3390/nu12092757

79. D'Avolio A, Avataneo V, Manca A, Cusato J, De Nicolò A, Lucchini R, Keller F, Cantù M (2020) 25-Hydroxyvitamin D concentrations are lower in patients with positive PCR for SARS-CoV-2. Nutrients 12(5):1359. https://doi.org/10.3390/nu12051359

80. Carpagnano GE, Di Lecce V, Quaranta VN, Zito A, Buonamico E, Capozza E, Palumbo A, Di Gioia G, Valerio VN, Resta O (2020) Vitamin D deficiency as a predictor of poor prognosis in patients with acute respiratory failure due to COVID-19. J Endocrinol Invest. https://doi.org/10.1007/s40618-020-01370-x

81. Luo X, Liao Q, Shen Y, Li H, Cheng L (2021) Vitamin D deficiency is associated with COVID-19 incidence and disease severity in Chinese People. J Nutr. https://doi.org/10.1093/jn/nxaa332

82. Rastogi A, Bhansali A, Khare N, Suri V, Yaddanapudi N, Sachdeva N, Puri GD, Malhotra P (2020) Short term, high-dose vitamin D supplementation for COVID-19 disease: a randomised, placebo-controlled, study (SHADE study). Postgrad Med J. https:// doi.org/10.1136/postgradmedj-2020-139065

83. Annweiler C, Hanotte B, Grandin de l'Eprevier C, Sabatier JM, Lafaie L, Célarier T (2020) Vitamin D and survival in COVID-19 patients: a quasi-experimental study. J Steroid Biochem Mol Biol. https://doi.org/10.1016/j.jsbmb.2020.105771

84. Murai IH, Fernandes AL, Sales LP, Pinto AJ, Goessler KF, Duran CSC, Silva CBR, Franco AS, Macedo MB, Dalmolin HHH (2020) Effect of vitamin D supplementation vs placebo on hospital length of stay in patients with severe COVID-19: a multicenter, doubleblind, randomized controlled trial. medRxiv. https://doi.org/10. 1101/2020.11.16.20232397

85. Zwerina K, Baum W, Axmann R, Heiland GR, Distler JH, Smolen J, Hayer S, Zwerina J, Schett G (2011) Vitamin D receptor regulates TNF-mediated arthritis. Ann Rheum Dis 70(6):1122-1129. https://doi.org/10.1136/ard.2010.142331

86. Bassatne A, Basbous M, Chakhtoura M, El Zein O, Rahme M, ElHajj Fuleihan G (2021) The link between COVID-19 and Vitamin D (VIVID): a systematic review and meta-analysis. Metabolism. https://doi.org/10.1016/j.metabol.2021.154753

87. Bayramoğlu E, Akkoç G, Ağbaş A, Akgün Ö, Yurdakul K, Selçuk Duru HN, Elevli M (2021) The association between vitamin D levels and the clinical severity and inflammation markers in pediatric COVID-19 patients: single-center experience from a pandemic hospital. Eur J Pediatr. https://doi.org/10.1007/ s00431-021-04030-1

88. Grant WB, Lahore H, McDonnell SL, Baggerly CA, French CB, Aliano JL, Bhattoa HP (2020) Evidence that vitamin D supplementation could reduce risk of influenza and COVID-19 infections and deaths. Nutrients 12(4):988. https://doi.org/10.3390/ nu12040988

Publisher's Note Springer Nature remains neutral with regard to jurisdictional claims in published maps and institutional affiliations. 